\title{
Are Wildfires Knocking on the Built-Up Areas Door?
}

\author{
Leone D. Mancini ${ }^{1}$ (1), Mario Elia ${ }^{2, *}$ (1) , Anna Barbati ${ }^{1}$, Luca Salvati ${ }^{3}$, Piermaria Corona $^{3}$ (D), \\ Raffaele Lafortezza $^{2}$ (i) and Giovanni Sanesi ${ }^{2}$ \\ 1 Department for Innovation in Biological, Agro-Food and Forest Systems (DIBAF), University of Tuscia, \\ Via S. Camillo de Lellis snc, I-01100 Viterbo, Italy; leone.mancini@unitus.it (L.D.M.); \\ barbati.sisfor@unitus.it (A.B.) \\ 2 Department of Agricultural and Environmental Sciences, University of Bari 'Aldo Moro', \\ Via Amendola 165/A, I-70126 Bari, Italy; raffaele.lafortezza@uniba.it (R.L.); giovanni.sanesi@uniba.it (G.S.) \\ 3 CREA, Research Centre for Forestry and Wood, Viale Santa Margherita 80, I-52100 Arezzo, Italy; \\ luca.salvati@crea.gov.it (L.S.); piermaria.corona@crea.gov.it (P.C.) \\ * Correspondence: mario.elia@uniba.it
}

Received: 24 March 2018; Accepted: 24 April 2018; Published: 28 April 2018

\begin{abstract}
Human-started fires represent the vast majority of wildfires in Mediterranean countries. The current expansion of human settlements into fire-prone territories has led to the creation of landscapes where anthropogenic developments merge with wildland areas. In this context, understanding the role of distance from built-up areas in shaping coarse-scale wildfire spatial patterns is a major concern. Proximity to cities has become an important factor that may increase the probability of wildfires in wildland-urban interfaces. To this issue, we developed an assessment of wildfire distribution in Italy over an 8-year period (2007-2014) to quantify fire occurrence and recurrence as a function of distance from built-up areas. Our findings suggest a positive relationship between the distance from built-up areas and fire incidence (i.e., ratio between burnt forest area and total forest area), whereas a negative relation was found between distance from built-up areas and fire frequency and recurrence; thus, there are more recurring yet smaller sized-fires near built-up areas. Fifty percent of fire events and more than two-thirds of recurrent fires occur within $200 \mathrm{~m}$ from built-up areas. On the other hand, the considerable amount of such fire events never reaches an incidence higher than $10 \%$ in flat areas and $30 \%$ in hilly and mountainous areas. More broadly, quantitative knowledge about where fires occur is essential to ensure appropriate fire management throughout large territories. With this in mind, our investigation intends to provide a solid base for further studies in landscapes with a high component of human-dominated land use.
\end{abstract}

Keywords: forest fire; fire recurrence; fire incidence; Mediterranean region; contour plot; Wildland Urban Interface

\section{Introduction}

Forest fire is an ecological factor in the Mediterranean region that often determines a wide range of impacts on ecosystem services [1]. The capability to understand and predict spatial patterns of forest fire occurrence and recurrence is crucial to improve the effectiveness of fire management resource allocation throughout large territories [2]. This is a remarkably complex research issue due to the multiple biophysical and socioeconomic drivers interacting over different spatial and temporal scales (e.g., [3-5]). Changes in wildfire driving forces (e.g., human pressure, climate change) can generate either slow or abrupt modifications in the spatial distribution of forest fires at the regional scale. Assessing and understanding the spatial patterns of wildfires may be a difficult task owing to limitations in fire recording protocols and the complexity of concurrent factors affecting wildfire ignition and spread. However, this knowledge is essential for designing and promoting 
sustainable land management strategies that incorporate effective measures for fire prevention and suppression [6-8].

Earlier studies have investigated the factors affecting wildfire spatial distribution [9]. A high probability of fire occurrence was ascribed to weather (e.g., [10,11]), climate (e.g., [12-14]), landscape fuel conditions (e.g., [15,16]), soil moisture (e.g., [17]), ignition agents (e.g., [18,19]), and human pressure (e.g., $[20,21])$. Large-scale analyses investigating the role of each factor are often partial and not exhaustive. There is a need to develop more comprehensive approaches incorporating the stochastic dimension associated to wildfires and the importance of spatial variability in local environmental conditions and socioeconomic contexts.

Human-induced fires represent the vast majority of wildfires in many regions of the world [22-24], particularly in the countries of the Mediterranean region [25,26]. Currently, built-up areas and human pressure into the countryside have not only converted and altered farms and forests but have also produced a mixture of urbanized and rural lands. In addition, the expansion of human settlements into fire-prone landscapes has led to the creation of landscapes where built-up areas merge with wildland areas, namely Wildland-Urban Interfaces (WUIs) [27]. The interplay of biophysical and socioeconomic factors, such as fuel load accumulation, lack of management, proximity to main roads and built-up areas, and seasonal peaks of population density, creates conditions for potential fire ignition and spread. These landscapes, defined as potential forest fire environments, require specific fire protection strategies for defending people, infrastructures, and housing asset values but also to guarantee the provision of ecosystem services [28]. In this context, forest fires can cause remarkable damages to people living in these areas that may be on similar scales to the damages that have recently affected cities like Athens [29], Moscow [30], and Coimbra [31].

Based on these premises, understanding the role of distance from built-up areas in shaping wildfire spatial patterns is becoming a major concern. In the last decade, proximity to cities was considered and studied as an important factor increasing wildfire probability (e.g., [32,33]). Gralewicz et al. [34] identified human proximity and elevation as influential factors of fire susceptibility in Canada. Human impact on fire occurrence and recurrence is primarily a product of population density and road accessibility [34]. Darques [35] considered that the distance to populated places might play a crucial role in determining the growth pattern of wildfires. Based on this evidence, the use of proximity measures to built-up areas in assessing human influence on forest fires has been largely implemented in recent literature [36]. At the same time, elevation is expected to substantially influence fire ignition and spread through fuel moisture and altitudinal zonation of forest vegetation types [37]. All other factors being equal, fuel moisture tends to increase with elevation due to different precipitation levels and temperatures [10,38], while different forest types are characterized by intrinsically different flammability levels $[37,39,40]$.

In the Mediterranean region, various studies have investigated the spatial patterns of wildfires [36,41-57], but none of them have used complete (i.e., all wildfires) spatial datasets (i.e., datasets of mapped wildfire polygons, see Mancini et al. [58]) on a national scale. Further, all these studies did not account for recurrent wildfires despite their key role in driving ecological processes and forest resilience $[2,59,60]$.

In this research, we assessed wildfire distribution in Italy over a period of 8 years (2007-2014) to quantify fire occurrence and recurrence as a function of distance from built-up area in order to provide a solid base for further studies in landscapes with a high component of human-oriented land use.

\section{Materials and Methods}

\subsection{Study Area}

Italy is geographically located between $36^{\circ}$ and $47^{\circ} 30^{\prime}$ north latitude and $5^{\circ} 30^{\prime}$ and $18^{\circ} 30^{\prime}$ east longitude, extending for $301,330 \mathrm{~km}^{2}$, with $23 \%$ of the area classified as lowlands, $42 \%$ as uplands, and $35 \%$ as mountainous lands. Its complex orography is due to the presence of two main mountain 
ranges: the Alps in the north and the Apennines in the center-south. In Italy, climate is highly variable following the latitudinal and altitudinal gradients and the distance from the sea, and ranges from Mediterranean warm to temperate cool.

The forested area is approximately $100,000 \mathrm{~km}^{2}$. Overall, $32 \%$ of forest formations are included in the Alpine bio-geographical region, 16\% in the Continental region, and 52\% in the Mediterranean region (sensu the Habitat Directive of the European Commission 43/92). The most widespread forest formations are dominated by various oak species (Quercus spp.) and European beech (Fagus sylvatica L.). A large portion of the broadleaved forests area is managed as coppices [61]. Among conifers, the most widely represented forest types (sensu Barbati et al. [62]) are dominated by Norway spruce (Picea abies (L.) H. Karst.), followed by mountain pines (e.g., Pinus sylvestris L. and P. nigra J.F. Arnold) and Mediterranean pines (P. halepensis Mill., P. pinaster Aiton, and P. pinea L.). Mixed forests (sensu Bravo-Oviedo et al. [63]) are also widespread.

\subsection{Forest Fires in Italy}

Over the past 20 years, a total of 1,100,000 ha of forest land have been burnt in Italy. An average of 11,000 fires occur annually, burning more than 50,000 ha of forests. The largest wildfires are concentrated in southern Italy and the main islands [64]. In northern Italy, wildfires occur mostly over the first quarter of the year (from January to March), a period when herbaceous vegetation is arid and prone to ignition due to low rainfall and a flow of northern dry winds. Such a condition is especially common in the foothills of the Alps, up to $800 \mathrm{~m}$, and at high elevations in the Apennines. By contrast, in southern Italy the highest probability of wildfire occurrence is essentially in the third quarter of the year (from June to August). Lack of rain and high air temperatures, possibly coupled with strong winds especially at an elevation up to $700 \mathrm{~m}$ a.s.l., result in dry fuel conditions that favor fire ignition and spread [40]. Moriondo et al. [65] found that future scenarios of climate change in Italy are expected to produce the highest increase in annual extreme events in all of Mediterranean Europe.

Mancini et al. [58] reported the distribution of fires per fuel types in Italy during the period 2007-2014, when nearly 150,000 hectares of forests were burned. Deciduous oak forests (6843 fires, 44,544 hectares) and broad-leaved evergreen forests (2868 fires, 22,880 hectares) are the most affected forest types both in terms of number of fires and sizes of burned areas, while Mediterranean pine forests are the most affected in relative terms.

\subsection{Geospatial Datasets}

Based on the perimeters of 33,504 forest fires recorded from 2007 to 2014, as provided by the Italian National Forest Service (Corpo Forestale dello Stato, CFS), we compiled an 8-year fire history of Italy (Figure 1). These datasets can have limitations and may contain errors. In different regions of Italy, often the methods of data collection are different, thus generating problems in obtaining reliable and verified data. In order to not fall into errors, we decided to use a time period that is neither too old (considering that we used the forest layer of 2012) nor too recent. For each event, data collection was based on defining the exact geographical position of the ignition point and a field GPS-based delimitation of the burnt area. The database contains all the fires recorded by the CFS, and we assumed the dataset to be complete and reliable, complete with the inclusion of even the smallest fires. The largest recorded size of burnt area was 10,550 ha, while the total burnt area during the study period was nearly 672,037 ha. The most critical situation was recorded in 2007 with over 170,000 hectares burned, while we have the lowest value in 2013 (43,770 hectares).

The forest High Resolution Layer (HRL) [66], including a 20-m resolution raster map of dominant leaf type $(20 \times 20 \mathrm{~m})$ provided by the Copernicus Land Monitoring Service carried out by the European Earth monitoring program, was used to distinguish forest fires from fires involving other non-urban land-use classes. Forest land was typically characterized using the most updated geospatial dataset (2012) provided by the Corine Land Cover initiative 1:100,000 [67,68]; the 4th hierarchical level of CLC land-use nomenclature system assures a complete mapping of forest types in Italy [69]. 


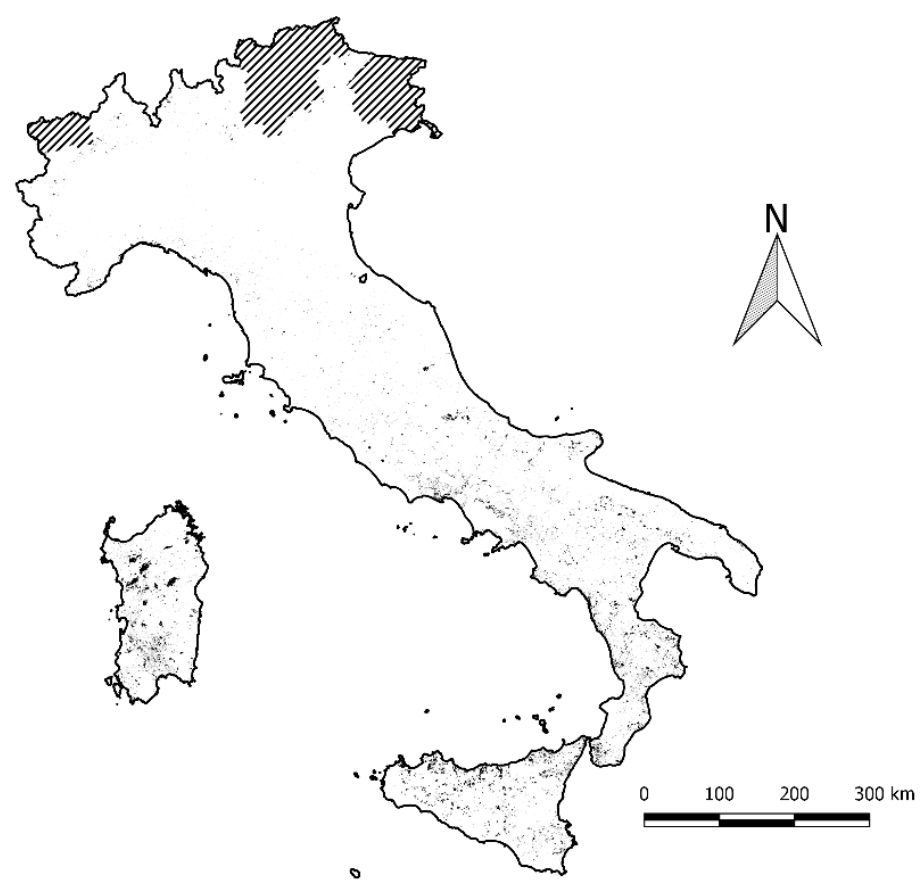

Figure 1. Map of the study area with fire perimeters of our dataset. Striped areas have missing values.

We used the Imperviousness Degree HRL [70], 20-m raster dataset, dated 2012 and provided by European Environment Agency, to identify built-up areas, referring to biophysical characteristics, and thus including roads, fabrics, and settlements. The IMD map illustrates the spatial distribution of artificially sealed areas, including the level of soil sealing per area unit [70].

\subsection{Data Processing}

In order to assess the frequency and incidence of forest fire occurrence and recurrence, we carried out the following analyses: (i) we created the distance raster from the built-up areas (i.e., pixels with imperviousness $>0 \%$ ); for each fire polygon of the collected geodataset (see section above) we assessed the frequency distribution of fires according to 100-m distance class intervals from built-up areas; (ii) for each forest polygon of the CLC map (CLC class 31) affected by fire, we assessed: the total area of the polygon, the burnt area, and incidence as the ratio between burnt area and the total area of the polygon; we also assessed the mean incidence values for each distance class (100-m interval) from built-up areas; (iii) to assess forest fire recurrence, we selected polygons where fire events occurred at least twice between 2007 and 2014 and recorded the frequency and incidence of recurring fires according to distance class (100-m ramp) from built-up areas. We used a contour plot to investigate the spatial relationships between fire incidence and distance from built-up areas, and also included elevation as a relevant influential factor. As mentioned in the introduction, a contour plot diagram for a function of two variables is a curve connecting points where the function has the same value.

Lastly, we used Spearman's $r$ nonparametric correlation analysis to assess relationships between fire incidence and the considered landscape variables (elevation and distance from built-up areas); significance was tested at $p<0.05$ after Bonferroni's correction for multiple comparisons [71,72].

\section{Results}

On the whole, although weak, Spearman's $r$ correlation showed a positive statistical association between distance from built-up areas and both fire incidence ( $\mathrm{rs}=0.12, p<0.05$ ), fire recurrence incidence ( $\mathrm{rs}=0.07, p<0.05$ ), and average burnt area per event ( $\mathrm{rs}=0.27, p<0.05$ ). A negative association between elevation and fire incidence $(\mathrm{rs}=-0.10, p<0.05)$ and fire recurrence $(\mathrm{rs}=-0.11$, 
$p<0.05)$ can also be observed too. Fire size distribution in the 2007-2014 time interval was significantly explained by a power-law statistical function over many orders of magnitude, as shown for other case studies (e.g., by Malamud et al. [73] and by Ricotta et al. [74]). Of note, 24,347 events were less than 10 ha in size and only 996 fires extended to more than 100 ha; however, even if these last fires constituted less than $3 \%$ of the total fires recorded in Italy, they accounted for $47 \%$ of the total area burnt between 2007 and 2014 (Figure 2).

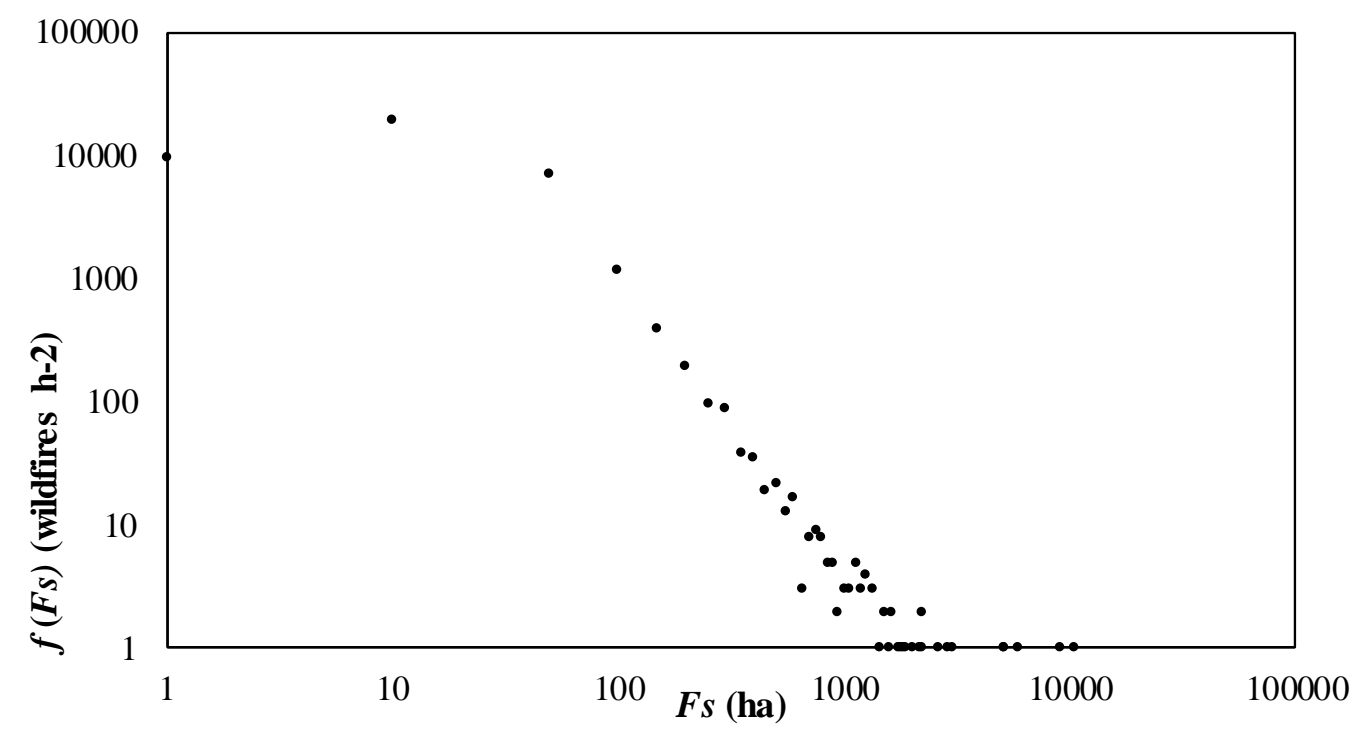

Figure 2. Normalized frequency-size statistics of forest fires in Italy within the 2007-2014 time interval.

The $x$-axis $F s$ indicates burnt area and the $y$-axis $f(F s)$ represents normalized frequency densities.

The distribution of forest fires by distance class from built-up areas (Figure 3) showed a similar trend for both occurrence and recurrence of forest fires. The frequency of fire occurrence decreases as the distance from built-up areas increases, for example, from 34\% (100 m) to 13\% (200 m). Fire recurrence decreased from $21 \%(100 \mathrm{~m})$ to $15 \%(200 \mathrm{~m})$. More than $70 \%$ of the fire events occurred within $500 \mathrm{~m}$ from built-up areas, while more than $70 \%$ of the recurring fires were within $600 \mathrm{~m}$ from built-up areas.

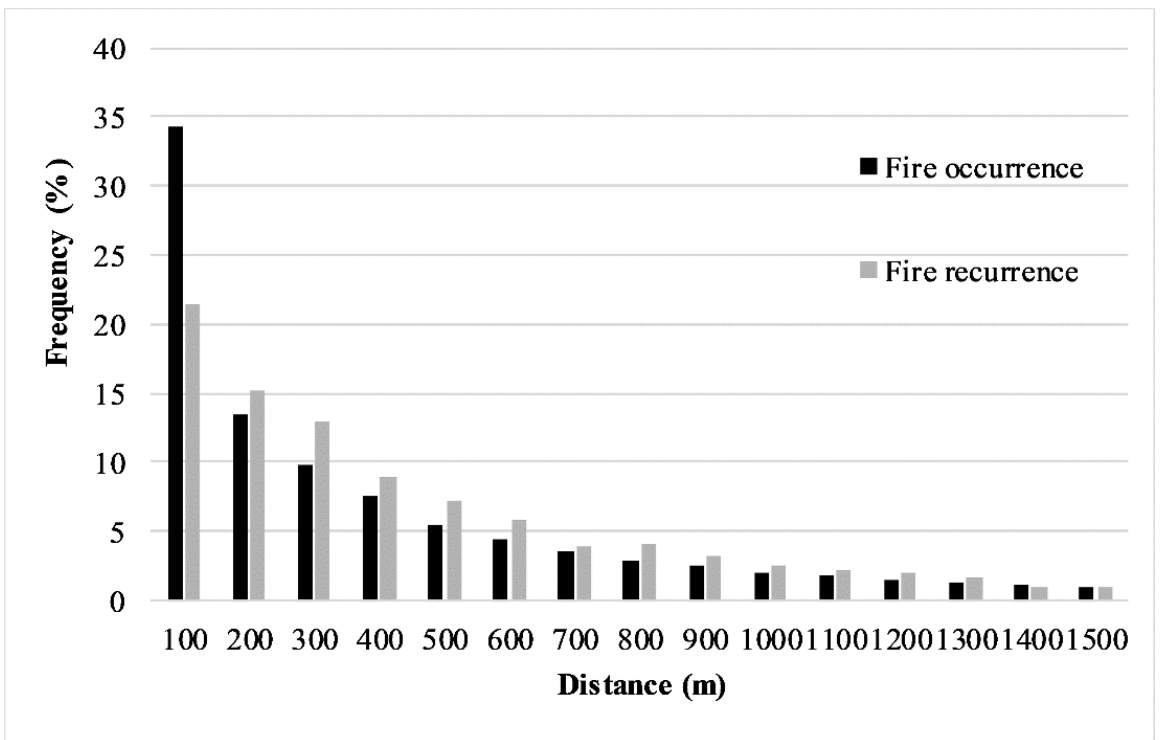

Figure 3. Relative frequency of forest fire events according to distance class from the built-up areas. 
Figure 4 shows the spatial variations in fire frequency by elevation. Fire frequency decreased as elevation increased. Fire occurrence and recurrence were extremely high at elevations up to $400 \mathrm{~m}$ a.s.l., and overall, $74 \%$ of forest fires and $77 \%$ of the recurring fires occurred at elevations below $600 \mathrm{~m}$ a.s.l.

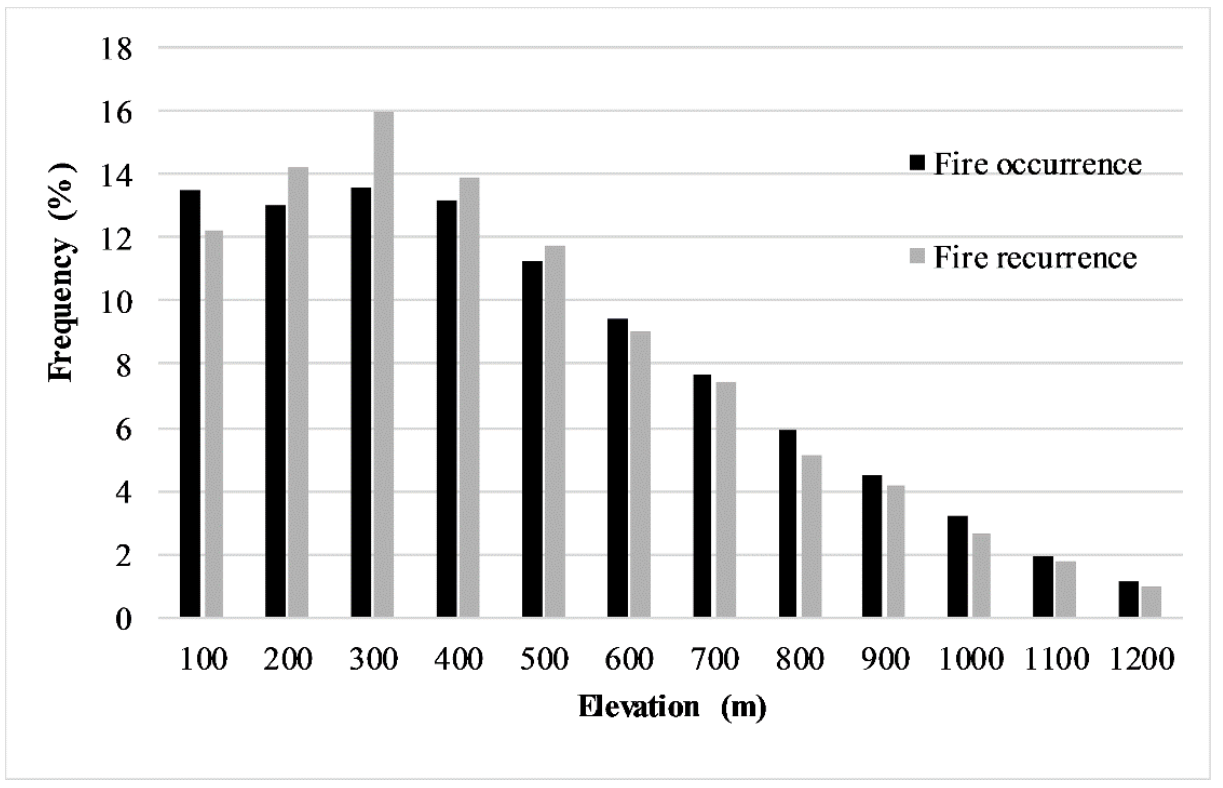

Figure 4. Relative frequency of forest fire events by elevation class.

Forest fire incidence showed a more dispersed pattern at increasing distances from built-up areas (Figure 5). However, the highest values of fire incidence (i.e., 15-20\% for fire occurrence and $12-14 \%$ for fire recurrence) were observed at distances $>1000 \mathrm{~m}$; by contrast, the lowest values (i.e., $<10 \%$ for fire occurrence and $<3 \%$ for fire recurrence) were found within $200 \mathrm{~m}$ from built-up areas. This trend was also reflected by the distribution of average burnt area per event with respect to distance from built-up areas (Figure 6).

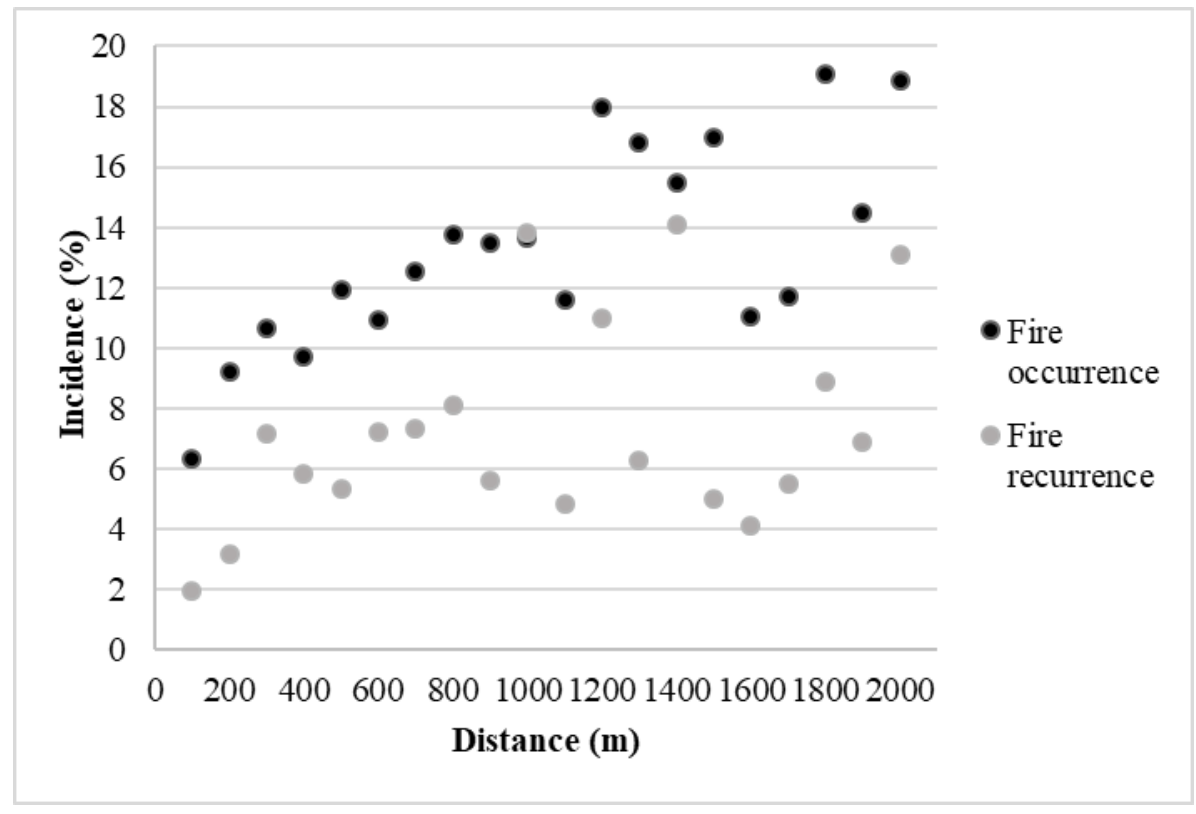

Figure 5. Mean values of fire incidence according to distance class from the built-up areas. 


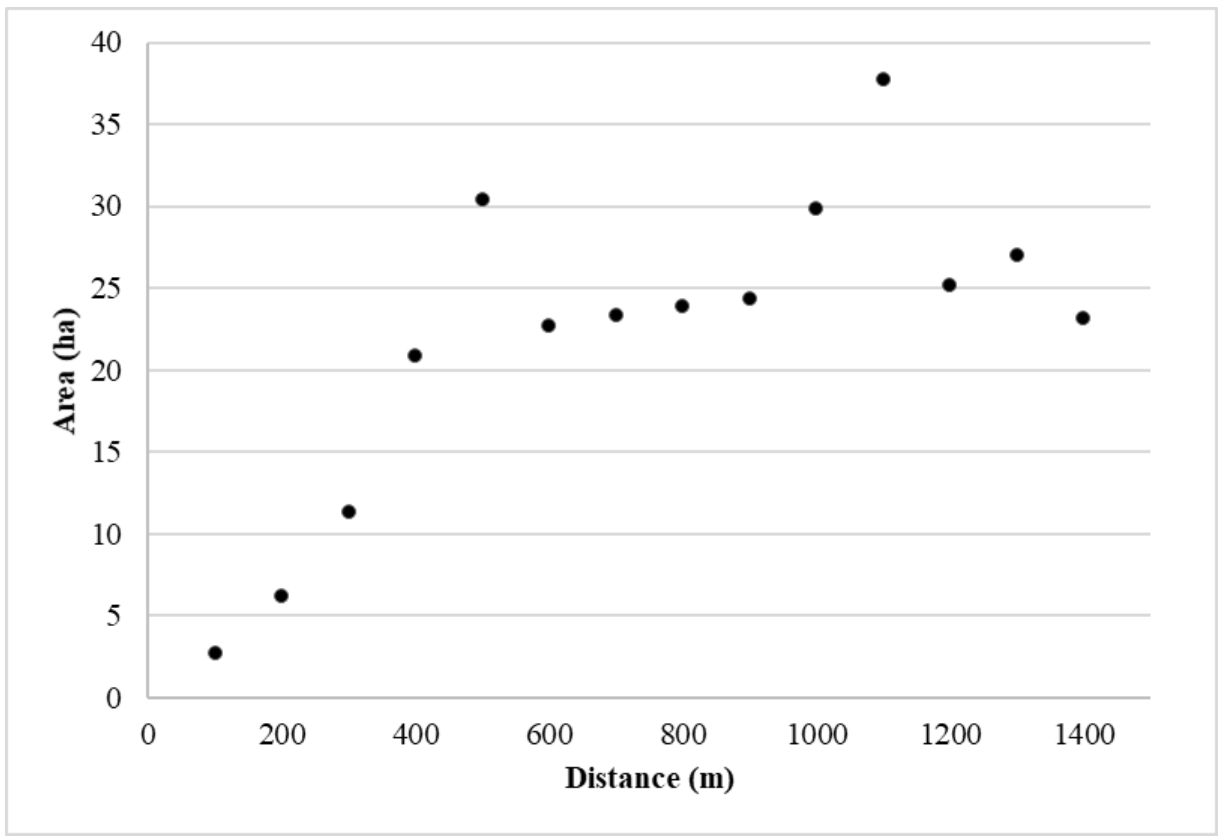

Figure 6. Mean values of burnt area per event according to distance class from the built-up areas.

The share of forest lands affected by single or repeated burning decreases as elevation increases. Fire incidence ranged between $12 \%$ and $15 \%$ up to an elevation of $<700 \mathrm{~m}$, being systematically lower than $10 \%$ at an elevation of $>1200 \mathrm{~m}$ a.s.l.; fire recurrence reached the highest values in correspondence of the 100,200 , and $300 \mathrm{~m}$ a.s.l. elevation classes $(13.7 \%, 9.1 \%$, and $8.5 \%$, respectively) and the lowest values $(<2 \%)$ above $1200 \mathrm{~m}$ a.s.l.

Figure 7 illustrates the values of fire incidence considering both distance from built-up areas and elevation. The contour plot shows areas where forest fire incidence reached maximum values, i.e., at an elevation of approximately $800 \mathrm{~m}$ and a distance of $1800 \mathrm{~m}$ from built-up areas. We found other critical values for elevations less than $550 \mathrm{~m}$ and distances from built-up areas greater than $1800 \mathrm{~m}$.

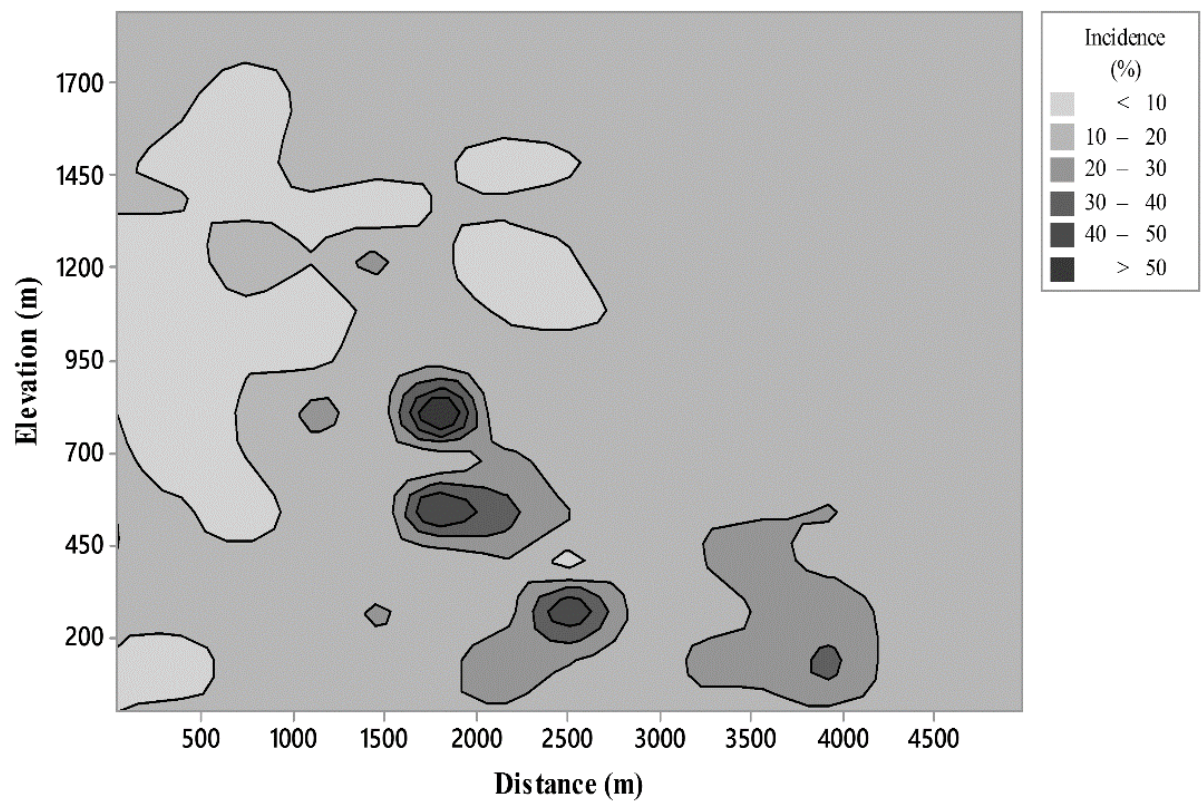

Figure 7. Contour plot diagram where fire incidence is shown as a function of elevation and distance from built-up areas. 
In the case of fire recurrence incidence (Figure 8), the highest values were recorded at an elevation of about $600 \mathrm{~m}$ and a distance of $2700 \mathrm{~m}$ from built-up areas.

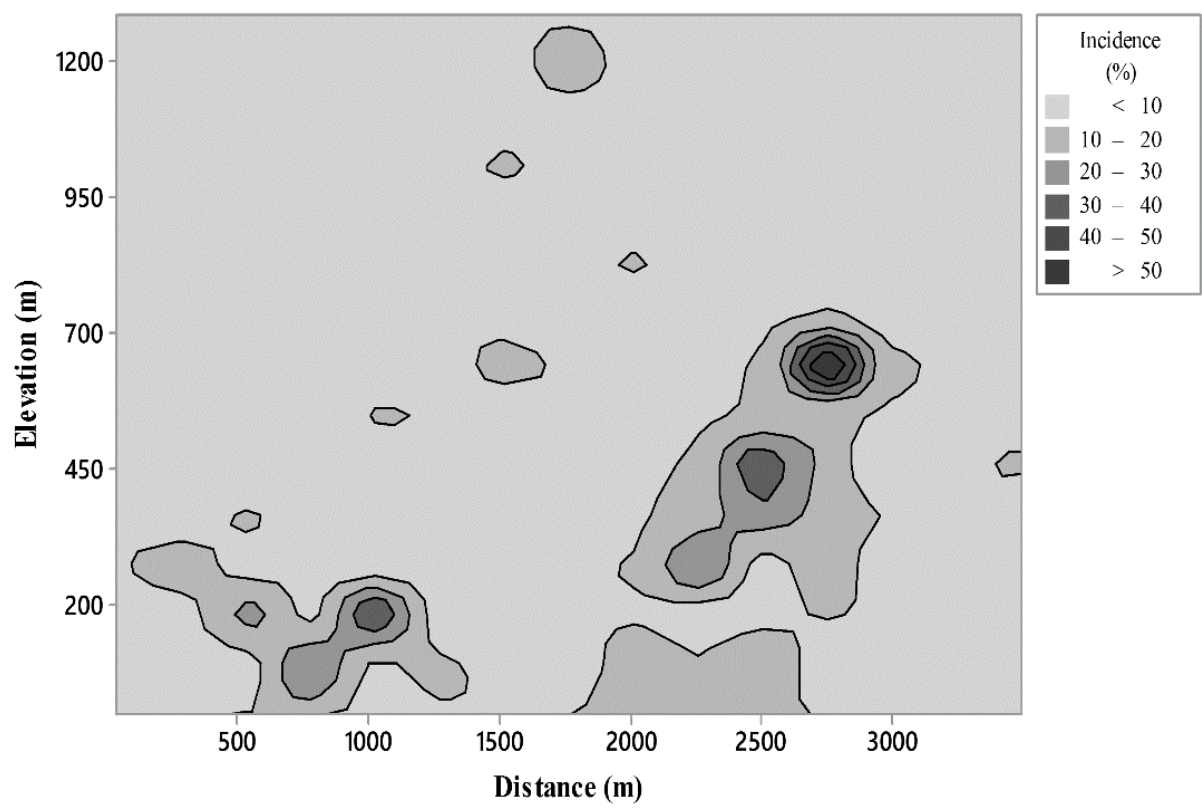

Figure 8. Contour plot diagram where fire recurrence incidence is shown as a function of elevation and distance from built-up areas.

\section{Discussion}

We analyzed the spatial distribution of forest fires in the Italian peninsula during the 2007-2014 time period. In particular, we investigated two pivotal issues of fire regime: frequency and incidence of forest fires according to relevant territorial predictors such as distance from built-up area and elevation. Notably, distance from built-up areas proved to be one of the most important predictors of wildfire occurrence in landscapes affected by widespread urbanization; this was expected, as in the Mediterranean region the large majority of wildland fires are caused by humans [36,75]. On the other hand, our results indicate that there is a negative relation between distance from built-up areas and fire frequency and recurrence but also a positive relation between the distance from built-up areas and fire incidence: thus, there are more fires, and more recurring events, in closer proximity to built-up areas, but the burnt areas that are closer to built-up areas are usually smaller than what is typically observed in more distant areas.

Our findings, documented on a large (national) scale, are in line with previous local studies affirming that as the distance to roads, urban settlements, and built-up areas increases, fire occurrence decreases (e.g., [36,41,42,45-48,50-53,55,56,76]), and fire incidence increases (e.g., [54,77]). In the examined case, nearly 50\% of fire occurrence and 36\% of recurrent fires occurred within $200 \mathrm{~m}$ from built-up areas. Interestingly, a 200-m buffer has been considered to be particularly suitable in the definition of WUIs in Europe [78]: this buffer area should play a key role in the management of prevention activities. Nevertheless, in Italy, such a considerable amount of fires never reached an incidence higher than $10 \%$ in flat areas $(<200 \mathrm{~m})$ and higher than $30 \%$ in hilly and mountainous areas in the considered period.

Territorial zones closer to man-made settlements are thus more likely to burn due to direct human activities and road accessibility (Figure 3). On the other hand, in our national-scale study we found the lowest values of burnt area per event in those zones. This is most likely a result of higher efficiency of fire management in areas where fires may pose significant direct risks to people, infrastructures, and asset values. Proximity to roads may make suppression operations more feasible, and such a 
proximity is even usually considered a priority zone when managing emergency calls and interventions (e.g., [79-82]).

Elevation also significantly influences both fire frequency and incidence. Contour plots suggest that elevation and distance from built-up areas represent the most critical combination in terms of fire incidence of single or recurrent fires; these hotspots of fire incidence are located in hilly and low mountain rural areas (1800 to $2700 \mathrm{~m}$ from built-up areas, at an elevation between 600 and $800 \mathrm{~m}$ ).

Quantitative knowledge about where wildfires ignite and spread is essential to ensure appropriate fire management throughout large territories: any rational decision needs to be the outcome of evidence-based considerations [83]. The ability to assess and understand how patterns of wildfires are distributed across large territories helps decision makers to improve the effectiveness of fire prevention, detection, and the allocation of firefighting resources. This issue is particularly crucial for managing fires under the increasing growth of "WUI-scapes". The use of such a strategy helps in the effective protection of overall ecosystem services [84,85].

\section{Conclusions}

This study investigated forest fires on a large-scale, covering the entire territory of Italy from both "horizontal" (distance from built-up areas) and "vertical" (elevation) points of view. Once spatial patterns of forest fire occurrence and recurrence across landscapes are identified and analyzed following this approach, fire managers can use this information to answer questions related to fire risk management, especially under extreme weather and fuel conditions. Such questions can range from what type of areas are likely to be treated (and where interventions should occur) to which fuel treatments are most effective for safeguarding people and urban settlements (e.g., [16,86,87]).

The spatial analysis presented here reveals two faces of the same coin: a disproportionately high wildfire occurrence close to built-up areas along with high fire incidence hotspots in quite distant rural areas. The results of this study suggest a greater need for fire management to tackle the complex issue of fire protection in WUIs, for example, the need to optimize the spatial allocation of fire suppression resources to defend people, infrastructures, or asset values. On the other hand, fire protection in rural areas requires the spatial allocation of fire prevention measures, such as prescribed burning and silvicultural tending (e.g., [40]) in order to reduce the size of burned forest areas.

Our findings result from an analysis of wildfires under a dynamic landscape framework and are consequently subject to change as new knowledge is obtained. Nevertheless, this explorative study may be of great practical significance because it not only corroborates prior research, but it also considers a large-scale perspective that will likely impact future analyses in this field. More broadly, the proposed analysis of large-scale spatial patterns of wildfires may apply to other countries (or regions) where time series of geospatial information on forest fire perimeters are available: ultimately, this would allow researchers and policymakers alike to quantitatively address the issue of whether wildfires are knocking on the doors of built-up-areas, and if so, to determine how best to respond.

Author Contributions: Leone D. Mancini and Mario Elia undertook the data processing and analyses, Raffaele Lafortezza and Giovanni Sanesi guided the results interpretation, discussion and conclusion. Anna Barbati, Luca Salvati, Piermaria Corona contributed in data analysis and results interpretation. Mario Elia and Leone D. Mancini authored the first version of the manuscript and all the co-authors improved the version.

Acknowledgments: We fully acknowledge the provision of burned areas geodaset by Italian Forest Service (Corpo Forestale dello Stato), Regional Forest Services of Sardinia (Corpo forestale e di vigilanza ambientale) and Sicilia (Corpo Forestale della Regione Siciliana).

Conflicts of Interest: The authors declare no conflicts of interest.

\section{References}

1. Harper, A.R.; Doerr, S.H.; Santin, C.; Froyd, C.A.; Sinnadurai, P. Prescribed fire and its impacts on ecosystem services in the UK. Sci. Total Environ. 2018, 624, 691-703. [CrossRef] [PubMed] 
2. Moreira, F.; Viedma, O.; Arianoutsou, M.; Curt, T.; Koutsias, N.; Rigolot, E.; Barbati, A.; Corona, P.; Vaz, P.; Xanthopoulos, G.; et al. Landscape-wildfire interactions in southern Europe, implications for landscape management. J. Environ. Manag. 2011, 92, 2389-2402. [CrossRef] [PubMed]

3. Senici, D.; Chen, H.Y.; Bergeron, Y.; Cyr, D. Spatiotemporal variations of fire frequency in central boreal forest. Ecosystems 2010, 13, 1227-1238. [CrossRef]

4. Costa, L.; Thonicke, K.; Poulter, B.; Badeck, F.W. Sensitivity of Portuguese forest fires to climatic; human; and landscape variables, subnational differences between fire drivers in extreme fire years and decadal averages. Reg. Environ. Chang. 2011, 11, 543-551. [CrossRef]

5. Aldersley, A.; Murray, S.J.; Cornell, S.E. Global and regional analysis of climate and human drivers of wildfire. Sci. Total Environ. 2011, 409, 3472-3481. [CrossRef] [PubMed]

6. Hann, W.J.; Bunnell, D.L. Fire and land management planning and implementation across multiple scales. Int. J. Wildl. Fire 2001, 10, 389-403. [CrossRef]

7. Stephens, S.L.; Ruth, L.W. Federal forest-fire policy in the United States. Ecol. Appl. 2005, 15, 532-542. [CrossRef]

8. Williams, J. Exploring the onset of high-impact mega-fires through a forest land management prism. For. Ecol. Manag. 2013, 294, 4-10. [CrossRef]

9. Grala, K.; Grala, R.K.; Hussain, A.; Cooke, W.H.; Varner, J.M. Impact of human factors on wildfire occurrence in Mississippi, United States. For. Policy Econ. 2017, 81, 38-47. [CrossRef]

10. Bessie, W.C.; Johnson, E.A. The relative importance of fuels and weather on fire behavior in subalpine forests. Ecology 1995, 76, 747-762. [CrossRef]

11. Elia, M.; Lovreglio, R.; Ranieri, N.A.; Sanesi, G.; Lafortezza, R. Cost-Effectiveness of Fuel Removals in Mediterranean Wildland-Urban Interfaces Threatened by Wildfires. Forests 2016, 7, 149. [CrossRef]

12. Gillett, N.P.; Weaver, A.J.; Zwiers, F.W.; Flannigan, M.D. Detecting the effect of climate change on Canadian forest fires. Geophys. Res. Lett. 2004, 31. [CrossRef]

13. Mermoz, M.; Kitzberger, T.; Veblen, T.T. Landscape influences on occurrence and spread of wildfires in Patagonian forests and shrublands. Ecology 2005, 86, 2705-2715. [CrossRef]

14. Pausas, J.G.; Paula, S. Fuel shapes the fire-climate relationship, evidence from Mediterranean ecosystems. Glob. Ecol. Biogeogr. 2012, 21, 1074-1082. [CrossRef]

15. Romme, W.H. Fire and landscape diversity in subalpine forests of Yellowstone National Park. Ecol. Monogr. 1982, 52, 199-221. [CrossRef]

16. Elia, M.; Lafortezza, R.; Lovreglio, R.; Sanesi, G. Developing Custom Fire Behavior Fuel Models for Mediterranean Wildland-Urban Interfaces in Southern Italy. Environ. Manag. 2015, 56, 754-764. [CrossRef] [PubMed]

17. Finney, M.A. Design of regular landscape fuel treatment patterns for modifying fire growth and behavior. For. Sci. 2001, 47, 219-228.

18. Malamud, B.D.; Millington, J.D.; Perry, G.L. Characterizing wildfire regimes in the United States. Proc. Natl. Acad. Sci. USA 2005, 102, 4694-4699. [CrossRef] [PubMed]

19. Elia, M.; Lafortezza, R.; Colangelo, G.; Sanesi, G. A streamlined approach for the spatial allocation of fuel removals in wildland-urban interfaces. Landsc. Ecol. 2015, 29, 1771-1784. [CrossRef]

20. Rollins, M.G.; Swetnam, T.W.; Morgan, P. Evaluating a century of fire patterns in two Rocky Mountain wilderness areas using digital fire atlases. Can. J. For. Res. 2001, 31, 2107-2123. [CrossRef]

21. Lafortezza, R.; Tanentzap, A.J.; Elia, M.; John, R.; Sanesi, G.; Chen, J. Prioritizing fuel management in urban interfaces threatened by wildfires. Ecol. Indic. 2015, 48, 342-347. [CrossRef]

22. Goldammer, J.G.; Crutzen, P.J. (Eds.) Fire in the environment, scientific rationale and summary of results of the Dahlem Workshop. In Fire in the Environment, the Ecological; Atmospheric and Climatic Importance of Vegetation Fire; John Wiley and Sons: Toronto, ON, Canada, 1993.

23. Gill, A.M.; Stephens, S.L.; Cary, G.J. The worldwide "wildfire" problem. Ecol. Appl. 2013, 23, $438-454$. [CrossRef] [PubMed]

24. Moritz, M.A.; Batllori, E.; Bradstock, R.A.; Gill, A.M.; Handmer, J.; Hessburg, P.F.; Leonard, J.; McCaffrey, S.; Odion, D.C.; Schoennagel, T.; et al. Learning to coexist with wildfire. Nature 2014, 515, 58-66. [CrossRef] [PubMed]

25. Pausas, J.G.; Fernández-Muñoz, S. Fire regime changes in the Western Mediterranean Basin, from fuel-limited to drought-driven fire regime. Clim. Chang. 2012, 110, 215-226. [CrossRef] 
26. San-Miguel-Ayanz, J.; Moreno, J.M.; Camia, A. Analysis of large fires in European Mediterranean landscapes, lessons learned and perspectives. For. Ecol. Manag. 2013, 294, 11-22. [CrossRef]

27. Theobald, D.M.; Romme, W.H. Expansion of the US wildland-urban interface. Landsc. Urban Plan. 2007, 83, 340-354. [CrossRef]

28. Galiana-Martin, L.; Herrero, G.; Solana, J. A wildland-urban interface typology for forest fire risk management in Mediterranean areas. Landsc. Res. 2011, 36, 151-171. [CrossRef]

29. Salvati, L.; Ferrara, A. Do land cover changes shape sensitivity to forest fires in peri-urban areas? Urban For. Urban Green. 2014, 13, 571-575. [CrossRef]

30. Shaposhnikov, D.; Revich, B.; Bellander, T.; Bedada, G.B.; Bottai, M.; Kharkova, T.; Kvasha, E.; Lezina, E.; Lind, T.; Semutnikova, E.; et al. Mortality related to air pollution with the Moscow heat wave and wildfire of 2010. Epidemiology (Cambridge, Mass.) 2014, 25, 359. [CrossRef] [PubMed]

31. BBC News Portugal Forest Fires Kill 62 near Coimbra. Available online: http:/ /www.bbc.com/news/worldeurope-40316934 (accessed on 19 June 2017).

32. Yang, J.; He, H.S.; Shifley, S.R. Spatial controls of occurrence and spread of wildfires in the Missouri Ozark Highlands. Ecol. Appl. 2008, 18, 1212-1225. [CrossRef] [PubMed]

33. Liu, Z.; Yang, J.; Chang, Y.; Weisberg, P.J.; He, H.S. Spatial patterns and drivers of fire occurrence and its future trend under climate change in a boreal forest of Northeast China. Glob. Chang. Biol. 2012, 18, 2041-2056. [CrossRef]

34. Gralewicz, N.J.; Nelson, T.A.; Wulder, M.A. Factors influencing national scale wildfire susceptibility in Canada. For. Ecol. Manag. 2012, 265, 20-29. [CrossRef]

35. Darques, R. Mediterranean cities under fire. A critical approach to the wildland-urban interface. Appl. Geogr. 2015, 59, 10-21. [CrossRef]

36. Ganteaume, A.; Camia, A.; Jappiot, M.; San-Miguel-Ayanz, J.; Long-Fournel, M.; Lampin, C.A. review of the main driving factors of forest fire ignition over Europe. Environ. Manag. 2013, 51, 651-662. [CrossRef] [PubMed]

37. Fares, S.; Bajocco, S.; Salvati, L.; Camarretta, N.; Dupuy, J.L.; Xanthopoulos, G.; Guijarro, M.; Madrigal, J.; Hernando, C.; Corona, P. Characterizing potential wildland fire fuel in live vegetation in the Mediterranean region. Ann. For. Sci. 2017, 74, 1. [CrossRef]

38. Heyerdahl, E.K.; Brubaker, L.B.; Agee, J.K. Spatial controls of historical fire regimes, a multiscale example from the interior west, USA. Ecology 2001, 82, 660-678. [CrossRef]

39. Xanthopoulos, G.; Calfapietra, C.; Fernandes, P. Fire hazard and flammability of European forest types. In Post-Fire Management and Restoration of Southern European Forests; Moreira, F., Arianoutsou, M., Corona, P., De las Heras, J., Eds.; Springer: Dordrecht, The Netherlands, 2012; pp. 79-92.

40. Corona, P.; Ascoli, D.; Barbati, A.; Bovio, G.; Colangelo, G.; Elia, M.; Garfi, V.; Iovino, F.; Lafortezza, R.; Leone, V.; et al. Integrated forest management to prevent wildfires under Mediterranean environments. Ann. Silvicult. Res. 2014, 38, 24-45.

41. De Vasconcelos, M.P.; Silva, S.; Tome, M.; Alvim, M.; Pereira, J.C. Spatial prediction of fire ignition probabilities, comparing logistic regression and neural networks. Photogramm. Eng. Remote Sens. 2001, $67,73-81$.

42. Kalabokidis, K.D.; Konstantinidis, P.; Vasilakos, C. GIS analysis of physical and human impact on wildfire patterns. In Proceedings of the IV International Conference on Forest Fire Research \& Wildland Fire Safety, Coimbra, Portugal, 18-23 November 2002; Millpress: Rotterdam, The Netherlands, 2002.

43. Koutsias, N.; Allgöwer, B.; Conedera, M. What is common in wildland fire occurrence in Greece and Switzerland?-Statistics to study fire occurrence pattern. In Proceedings of the 4 th International Conference on Forest Fire Research, Luso, Portugal, 18-23 November 2002; Viegas, D.X., Ed.; Millpress Science Publishers: Rotterdam, The Netherlands, 2002.

44. Amatulli, G.; Rodrigues, M.J.; Trombetti, M.; Lovreglio, R. Assessing long-term fire risk at local scale by means of decision tree technique. J. Geophys. Res.-Biogeosci. 2006, 111. [CrossRef]

45. Badia-Perpinyá, A.; Pallares-Barbera, M. Spatial distribution of ignitions in Mediterranean periurban and rural areas, the case of Catalonia. Int. J. Wildl. Fire 2006, 15, 187-196. [CrossRef]

46. Lozano, F.J.; Suárez-Seoane, S.; de Luis, E. Assessment of several spectral indices derived from multi-temporal Landsat data for fire occurrence probability modelling. Remote Sens. Environ. 2007, 107, 533-544. [CrossRef] 
47. Lozano, F.J.; Suárez-Seoane, S.; Kelly, M.; Luis, E. A multi-scale approach for modeling fire occurrence probability using satellite data and classification trees. A case study in a mountainous Mediterranean region. Remote Sens. Environ. 2008, 112.3, 708-719. [CrossRef]

48. Romero-Calcerrada, R.; Novillo, C.J.; Millington, J.D.A.; Gomez-Jimenez, I. GIS analysis of spatial patterns of human-caused wildfire ignition risk in the SW of Madrid (Central Spain). Landsc. Ecol. 2008, 23, 341-354. [CrossRef]

49. Sebastián-López, A.; Salvador-Civil, R.; Gonzalo-Jiménez, J.; SanMiguel-Ayanz, J. Integration of socio-economic and environmental variables for modelling long-term fire danger in Southern Europe. Eur. J. For. Res. 2008, 127, 149-163. [CrossRef]

50. Martínez, J.; Vega-Garcia, C.; Chuvieco, E. Human-caused wildfire risk rating for prevention planning in Spain. J. Environ. Manag. 2009, 90, 1241-1252. [CrossRef] [PubMed]

51. Romero-Calcerrada, R.; Barrio-Parra, F.; Millington, J.D.A.; Novillo, C.J. Spatial modelling of socioeconomic data to understand patterns of human-caused wildfire ignition risk in the SW of Madrid (Central Spain). Ecol. Model. 2010, 221, 34-45. [CrossRef]

52. Catry, F.X.; Rego, F.C.; Bação, F.L.; Moreira, F. Modeling and mapping wildfire ignition risk in Portugal. Int. J. Wildl. Fire 2010, 18, 921-931. [CrossRef]

53. Badia, A.; Serra, P.; Modugno, S. Identifying dynamics of fire ignition probabilities in two representative Mediterranean wildland-urban interface areas. Appl. Geogr. 2011, 31, 930-940. [CrossRef]

54. Moreno, J.M.; Viedma, O.; Zavala, G.; Luna, B. Landscape variables influencing forest fires in central Spain. Int. J. Wildl. Fire 2011, 20, 678-689. [CrossRef]

55. Oliveira, S.; Oehler, F.; San-Miguel-Ayanz, J.; Camia, A.; Pereira, J.M. Modeling spatial patterns of fire occurrence in Mediterranean Europe using Multiple Regression and Random Forest. For. Ecol. Manag. 2012, 275, 117-129. [CrossRef]

56. Martínez-Fernández, J.; Chuvieco, E.; Koutsias, N. Modelling long-term fire occurrence factors in Spain by accounting for local variations with geographically weighted regression. Nat. Hazards Earth Syst. 2013, 13, 311-327. [CrossRef]

57. Rodrigues, M.; de la Riva, J.; Fotheringham, S. Modeling the spatial variation of the explanatory factors of human-caused wildfires in Spain using geographically weighted logistic regression. Appl. Geogr. 2014, 48, 52-63. [CrossRef]

58. Mancini, L.; Barbati, A.; Corona, P. Geospatial analysis of woodland fire occurrence and recurrence in Italy. Ann. Silvic. Res. 2017, 41, 41-47.

59. Ricotta, C.; Di Vito, S. Modeling the landscape drivers of fire recurrence in Sardinia. Italy. Environ. Manag. 2014, 53, 1077-1084. [CrossRef] [PubMed]

60. Barbati, A.; Corona, P.; D'amato, E.; Cartisano, R. Is Landscape a Driver of Short-term Wildfire Recurrence? Landsc. Res. 2015, 40, 99-108. [CrossRef]

61. Ciancio, O.; Corona, P.; Lamonaca, A.; Portoghesi, L.; Travaglini, D. Conversion of clearcut beech coppices into high forests with continuous cover, A case study in central Italy. For. Ecol. Manag. 2006, 224, 235-240. [CrossRef]

62. Barbati, A.; Marchetti, M.; Chirici, G.; Corona, P. European forest types and forest Europe SFM indicators, tools for monitoring progress on forest biodiversity conservation. For. Ecol. Manag. 2014, 321, 145-157. [CrossRef]

63. Bravo-Oviedo, A.; Pretzsch, H.; Ammer, C.; Andenmatten, E.; Antón, C.; Barbati, A.; Barreiro, S.; Brang, P.; Bravo, F.; Brunner, A.; et al. European Mixed Forests, definition and perspectives. For. Syst. 2014, 23, 518-533. [CrossRef]

64. CFS. Rapporto Annuale Incendi Boschivi [Annual Report on Forest Fires]; Corpo Forestale dello Stato: Rome, Italy, 2016.

65. Moriondo, M.; Good, P.; Durao, R.; Bindi, M.; Giannakopoulos, C.; Corte-Real, J. Potential impact of climate change on fire risk in the Mediterranean area. Clim. Res. 2006, 31, 85-95. [CrossRef]

66. FTY HRL Forest Type High Resolution Layer 2012. Available online: http://land.copernicus.eu/paneuropean/high-resolution-layers/forests/forest-type/view (accessed on 2 May 2016).

67. CLC Corine Land Cover 2012. Available online: http://www.sinanet.isprambiente.it/it/sia-ispra/ download-mais / corine-land-cover/corine-land-cover-2012-iv-livello/view (accessed on 2 May 2016). 
68. EEA CLC 2006 Technical Guidelines. EEA Technical Report No 17/2007. Available online: http:/ / www.eea. europa.eu/publications/technical_report_2007_17 (accessed on 2 May 2016).

69. ISPRA. La Realizzazione in Italia del Progetto Corine Land Cover 2006 [The Implementation in Italy of the Project Corine Land Cover 2006]; Report No. 131; Istituto Superiore per la Protezione e la Ricerca Ambientale: Rome, Italy, 2010; p. 49. (In Italian)

70. IMD HRL Imperviousness Degree High Resolution Layer 2012. Available online: http:/ / land.copernicus. eu/pan-european/high-resolution-layers/imperviousness/imperviousness-2012/view (accessed on 2 May 2016).

71. Duvernoy, I.; Zambon, I.; Sateriano, A.; Salvati, L. Pictures from the Other Side of the Fringe: Urban Growth and Peri-urban Agriculture in a Post-industrial City (Toulouse, France). J. Rural Stud. 2018, 57, 25-35. [CrossRef]

72. Pili, S.; Grigoriadis, E.; Carlucci, M.; Clemente, M.; Salvati, L. Towards Sustainable Growth? A Multi-criteria Assessment of (Changing) Urban Forms. Ecol. Indic. 2017, 76, 71-80. [CrossRef]

73. Malamud, B.D.; Morein, G.; Turcotte, D.L. Forest fires, an example of self-organized critical behavior. Science 1998, 281, 1840-1842. [CrossRef] [PubMed]

74. Ricotta, C.; Avena, G.; Marchetti, M. The flaming sandpile, self-organized criticality and wildfires. Ecol. Model. 1999, 119, 73-77. [CrossRef]

75. Lovreglio, R.; Leone, V.; Giaquinto, P.; Notarnicola, A. Wildfire cause analysis, four case-studies in southern Italy. iForest 2010, 3, 8-15. [CrossRef]

76. Ganteaume, A.; Long-Fournel, M. Driving factors of fire density can spatially vary at the local scale in south-eastern France. Int. J. Wildl. Fire 2015, 24, 650-664. [CrossRef]

77. Marques, S.; Borges, J.G.; Garcia-Gonzalo, J.; Moreira, F.; Carreiras, J.M.B.; Oliveira, M.M.; Cantarinha, A.; Botequim, B.; Pereira, J.M.C. Characterization of wildfires in Portugal. Eur. J. For. Res. 2011, 130, 775-784. [CrossRef]

78. Modugno, S.; Balzter, H.; Cole, B.; Borrelli, P. Mapping regional patterns of large forest fires in Wildland-Urban Interface areas in Europe. J. Environ. Manag. 2016, 172, 112-126. [CrossRef] [PubMed]

79. Setiawan, I.; Mahmud, A.R.; Mansor, S.; Mohamed Shariff, A.R.; Nuruddin, A. A GIS-grid-based and multi-criteria analysis for identifying and mapping peat swamp forest fire hazard in Pahang, Malaysia. Disaster Prev. Manag. 2004, 13, 379-386. [CrossRef]

80. Jaiswal, R.K.; Mukherjee, S.; Raju, K.D. Saxena R Forest fire risk zone mapping from satellite imagery and GIS. Int. J. Appl. Earth Obs. Geoinf. 2002, 4, 1-10. [CrossRef]

81. Kalabokidis, K.D.; Koutsias, N.; Konstantinidis, P.; Vasilakos, C. Multivariate analysis of landscape wildfire dynamics in a Mediterranean ecosystem of Greece. Area 2007, 39, 392-402. [CrossRef]

82. Mahdavi, A. Forests and rangelands? wildfire risk zoning using GIS and AHP techniques. Casp. J. Environ. Sci. 2012, 10, 43-52.

83. Corona, P. Consolidating new paradigms in large-scale monitoring and assessment of forest ecosystems. Environ. Res. 2016, 144, 8-14. [CrossRef] [PubMed]

84. Fernandes, P.M. Fire smart management of forest landscapes in the Mediterranean basin under global change. Landsc. Urban Plan. 2013, 110, 175-182. [CrossRef]

85. Schroder, S.A.K.; Tóth, S.F.; Deal, R.L.; Ettl, G.J. Multi-objective optimization to evaluate tradeoffs among forest ecosystem services following fire hazard reduction in the Deschutes National Forest, USA. Ecosyst. Serv. 2016, 22, 328-347. [CrossRef]

86. Kim, Y.H.; Bettinger, P.; Finney, M. Spatial optimization of the pattern of fuel management activities and subsequent effects on simulated wildfires. Eur. J. Oper. Res. 2009, 197, 253-265. [CrossRef]

87. Corona, P.; Ferrari, B.; Cartisano, R.; Barbati, A. Calibration assessment of forest flammability potential in Italy. iForest 2014, 7, 300. [CrossRef]

(C) 2018 by the authors. Licensee MDPI, Basel, Switzerland. This article is an open access article distributed under the terms and conditions of the Creative Commons Attribution (CC BY) license (http://creativecommons.org/licenses/by/4.0/). 